\title{
Evaluation of different drying models for jabuticaba peel, dried in spouted bed dryer through performance indicators and the impact on anthocyanins
}

Avaliação de diferentes modelos de secagem para casca de jabuticaba seca em leito de jorro através de indicadores de desempenho e o impacto para antocianinas

\author{
J. T. S. Santos ${ }^{1}$; J. V. Leite ${ }^{2}$; D. A. Anjos²; P. N. Oliveira²; A. M. Oliveira \\ Júnior $^{1,2}$; D. F.S. Souza ${ }^{3}$ \\ ${ }^{1}$ Graduate Program in Chemical Engineering, Federal University of Sergipe, zip code: 49100-000, São Cristóvão- \\ Sergipe, Brazil \\ ${ }^{2}$ Food Technology Department, Federal University of Sergipe, zip code: 49100-000, São Cristóvão-Sergipe, Brazil \\ ${ }^{3}$ Chemical Engineering Department, Federal University of Rio Grande do Norte, zip code: 59078-900, Natal- Rio \\ Grande do Norte, Brazil
}

*jessica.teles.ss@gmail.com

(Recebido em 25 de julho de 2017; aceito em 24 de maio de 2018)

\begin{abstract}
Jabuticaba fruit stands out for its energetic and nutritional value being widely consumed in the fresh form and used for the production of jellies, vinegar, wines, and liquor. The jabuticaba peel has a high content of natural antioxidants, such as carotenoids, anthocyanins, tocopherols, and phenolic compounds, these compounds give protection to the fruit. In order to promote preservation of the jabuticaba peel for an extended period of time, the drying process is applied to remove water from the product and, consequently, reduce the risks of microbial growth and enzymatic reactions. The objectives of this study were to evaluate four drying models for spouted bed drying of jabuticaba peel using the following performance indicators: accuracy factor $\left(\mathrm{A}_{\mathrm{f}}\right)$, bias factor $\left(\mathrm{B}_{\mathrm{f}}\right)$ and mean square error (RMSE), and analyze the impact of drying temperatures on the content of monomeric anthocyanins. The drying process was done in a pilot spouted bed dryer unit at temperatures: 50,60 and $70^{\circ} \mathrm{C}$ for $2.5 \mathrm{~h}$. The total monomeric anthocyanin content was determined using the $\mathrm{pH}$ differential method. It was observed that for the temperatures of $60^{\circ} \mathrm{C}$ and $70^{\circ} \mathrm{C}$, the Two-term, and Page models, respectively, are appropriated to describe the drying kinetic of the jabuticaba peel in a spouted bed drying under the studied conditions. Moreover, for anthocyanins content, it was noted that there was a greater degradation at the highest temperature studied $\left(70^{\circ} \mathrm{C}\right)$ as expected since anthocyanins are heat-sensitive substances.

Key-Words: Drying, Modeling, Myrciaria cauliflora
\end{abstract}

A jabuticaba se destaca por seu valor energético e nutricional sendo bastante consumida na forma in natura e utilizada para a produção de geleias, vinagres, vinhos e licor. A casca de jabuticaba possui alto teor de antioxidantes naturais, como carotenóides, antocianinas, tocoferóis e compostos fenólicos, que dão proteção ao fruto. Com o propósito de promover a conservação da casca por um período de tempo prolongado, aplica-se o processo de secagem para retirar a água do produto e com isto diminuir os riscos de crescimento microbiano e reações enzimáticas. O presente trabalho teve como objetivos avaliar quatro modelos de secagem da casca de jabuticaba em leito de jorro, utilizando os seguintes indicadores de desempenho: fator de precisão $\left(\mathrm{A}_{\mathrm{f}}\right)$, fator de viés $\left(\mathrm{B}_{\mathrm{f}}\right)$ e erro quadrático médio (RMSE), e analisar o impacto das temperaturas de secagem no conteúdo de antocianinas monoméricas. A secagem em leito de jorro foi conduzida em uma unidade piloto de secador de leito de jorro nas temperaturas: 50,60 e $70^{\circ} \mathrm{C}$ por $2,5 \mathrm{~h} . \mathrm{O}$ teor de antocianina monomérica total foi determinado utilizando o método diferencial de $\mathrm{pH}$. Observou-se que para as temperaturas de $60^{\circ} \mathrm{C}$ e $70^{\circ} \mathrm{C}$, os modelos de dois termos e Page, respectivamente, são mais adequados para descrever a cinética de secagem em leito de jorro da casca de jabuticaba, nas condições estudadas. Para antocianinas, foi possível observar que houve uma maior degradação para a maior temperatura estudada, $70^{\circ} \mathrm{C}$, como esperado, já que as antocianinas são termossensíveis.. Palavras-chave: Secagem, Modelagem, Myciaria cauliflora 


\section{INTRODUCTION}

Brazilian flora is rich in wild edible fruits, and among the most important native species Jabuticabeira stands out for its energetic and cultural value. The origin of its name comes from the Tupi language word "iapotikaba" meaning "stick fruit" and "fruit of which the jabuti is fed". The fruit tree is Myrciaria cauliflora Berg, which belongs to Myrtaceae family, and its cultivation prevails in subtropical weather areas being easily adapted in tropical weather areas [1]. Its fruit is widely consumed in fresh and processed form, such as jams, vinegar, wines, and liqueurs. Jabuticaba peel has a high content of carotenoids, anthocyanins, tocopherols, phenolic compounds, and natural antioxidants that give protection to the fruit [2].

Anthocyanin is a natural coloring which the color can vary between blue and red, and it can be applied as food coloring. Its functional properties of antioxidant activities act on the disease prevention [3]. The extraction method of anthocyanins is considered low cost in industrial scale with high convenience due to its classification as water soluble compound.

Several factors can change the color and stability of the anthocyanins such as temperature, exposition to the light, variation of $\mathrm{pH}$, the chemical structure of the molecule, solvent, storage, and its concentration [4]. In order to not have the thermal degradation and the reduction of the anthocyanins concentration, its extraction should not be at temperatures higher than $60{ }^{\circ} \mathrm{C}$ [5], and the quantification and acquisition of anthocyanins occur by the $\mathrm{pH}$ differential method, spectrophotometry, and chromatography.

The jabuticaba commercialization has been going through difficulties because this fruit is highly perishable presenting a short period of consumption due to its high content of water and sugars [6]. Thinking of improvements for the preservation of this fruit, the drying process has been used to remove the water of the product through the heat having the heat and mass transfer with water removal and consequent reduction of microbial growth and enzymatic reactions [7]. The application of this process increases the product's shelf life, the stability of the aromatic compounds at room temperature for long periods of time, degradation protection, weight reduction, and the availability of the product at any time of the year [8].

The spouted bed dryer was developed to dry wheat grains, and since then it has been used for the drying of other types of food. Operationally, the equipment consists of regions where the pneumatic transport of the particles varies with the velocity of the fluid which moves to the annular region sliding to the collector. Drying of fruit in spouted bed dryer has shown good performance with drying agent [9].

The study of drying systems, their sizing, optimization, and determination of the commercial application viability can be done by mathematical modeling. Drying modeling represents satisfactorily the moisture loss of the product during the drying period and brings as a benefit the reduction of experiments and costs related to the drying process [7]. In the literature, there are several types of models proposed to analyze the drying process of hygroscopic products: theoretical, semi-theoretical and empirical. Semi-theoretical models have been widely used due to their convenience of use because they reflect all the phenomena between theory and application based, in general, on Newton's cooling law, which is applied to mass transfer, assuming that during drying, the conditions are isothermal and the moisture transfer is restricted to the product's surface. To illustrate, some of the semi-theoretical models are Page, Henderson and Pabis, Newton, and Two-term. The Page model describes the drying process in an exponential model, where the model parameters are calculated according to the variables that influence the drying rate [10]. The Henderson and Pabis and Two-term models are better suited for adjusting the drying kinetic of agricultural products in a thin layer.

Therefore, in order to make full use of the nutritional value present in the jabuticaba peel and reduce the agroindustrial waste, it is necessary to know the yield of the compounds after drying for feasibility analysis. In addition, to avoid the exhaustive laboratory experiments, it is worth using the modeling to predict future behaviors. Thus, the objectives of the present work were to dry the jabuticaba peel in spouted bed dryer at different temperatures, analyze the drying impact on the anthocyanins, and select a semi-empirical mathematical model that best describes the drying kinetics at different temperatures using performance indicators. 


\section{MATERIALS AND METHODS}

The work was carried out at the Pilot Plant located in the Food Technology Department at the Federal University of Sergipe.

\subsection{Plant Material}

Jabuticaba fruits were acquired from a fruit and vegetable market center in Aracaju-SE and conducted to the lab in boxes.

\subsection{Spouted Bed Drying}

Spouted bed drying was done in a pilot unit of a spouted bed dryer at different temperatures $\left(50,60\right.$, and $\left.70{ }^{\circ} \mathrm{C}\right)$ for $2.5 \mathrm{~h}$. For the drying kinetics, samples were taken each 10 min during the first half hour of drying, and then two samples were taken at an interval of $15 \mathrm{~min}$, one sample after $30 \mathrm{~min}$, and the last point after $60 \mathrm{~min}$ of drying. Moisture analysis was done using the conventional oven method at $105^{\circ} \mathrm{C}$ for $24 \mathrm{~h}$. High density polyethylene was used as inert (area of $12.57 \pm 0.03 \mathrm{~m}^{2}$, volume $33.59 \pm 0.01 \mathrm{~m}^{3}$, and density $0.895 \pm 0.095 \mathrm{~g} / \mathrm{ml}$ ) in a ratio of $1: 3$ (fruit: inert).

\subsection{Mathematical Modeling}

For the purpose of mathematical modeling, the moisture ratio of the experimental data was determined by means of Equation 1.

(1)

$$
M R=\frac{\left(M(t)-M_{e q}\right)}{\left(M_{i}-M_{e q}\right)}
$$

Where:

MR is the moisture ratio;

$M(t)$ is the moisture at $t$ time in dry basis;

$\mathrm{M}_{\mathrm{eq}}$ is the equilibrium moisture in dry basis;

$\mathrm{M}_{\mathrm{i}}$ is the initial moisture in dry basis.

The experimental data on moisture ratio were adjusted to the models described in Table 1. It was used the Statistica ${ }^{\circledR}$ software version 7.0 for Windows, and it was applied a nonlinear regression analysis using the Levenberg-Marquardt method and minimum squares method as loss function.

Table 1. Drying mathematical models.

\begin{tabular}{lc}
\hline Mathematical Models & Equations \\
\hline Page Model & $M R=\exp \left(-k \cdot t^{n}\right)$ \\
Henderson and Pabis Model & $M R=a \cdot \exp (-k \cdot t)$ \\
Newton Model & $M R=\exp (-k \cdot t)$ \\
Two-term Model & $M R=a \cdot \exp \left(-k_{0} \cdot t\right)+b \cdot \exp \left(k_{1} \cdot t\right)$ \\
\hline
\end{tabular}

The definition of the most appropriated model was done by performance indicators shown in Table 2. The results were calculated using the Excel software version 2007 for windows. 
Table 2. Performance indicators of mathematical models.

Performance Indicators

Root mean square error (RMSE)

Bias factor $\left(B_{\mathrm{f}}\right)$

Accuracy factor $\left(\mathbf{A}_{\mathbf{f}}\right)$

\section{Equations}

$$
\begin{aligned}
R M S E & =\sqrt{\frac{\sum(\text { obs }- \text { pred })^{2}}{n}} \\
B_{f} & =10^{\frac{\Sigma \log \left(\frac{\text { pred }}{\text { obs }}\right)}{n}} \\
A_{f} & =10^{\frac{\Sigma\left|\log \left(\frac{\text { pred }}{\text { obs }}\right)\right|}{n}}
\end{aligned}
$$

\subsection{Anthocyanin Assay}

The total monomeric anthocyanin (TMA) content was determined using the $\mathrm{pH}$ differential method described by Giusti e Wrolstad [11], which is based on the structural transformation of the anthocyanin chromophore as a function of $\mathrm{pH}$.

The sample extract was prepared previously from the addition of ethanol to the jabuticaba peel in the ratio of (1:10) (sample: ethanol), then magnetic stirring was carried out for $2 \mathrm{~h}$, and the sample was filtered under vacuum and evaporated at $40^{\circ} \mathrm{C}$ and $-700 \mathrm{mmHg}$ using a rotary evaporator.

A spectrophotometer was used for spectral measurement at the maximum absorbance $(512 \mathrm{~nm})$ and $700 \mathrm{~nm}$, distilled water as the blank. For this, a $0.6 \mathrm{~g}$ sample of the extract was mixed with $10 \mathrm{ml}$ of distilled water. Aliquots of this solution were brought to $\mathrm{pH} 1.0$ (hydrochloric acid/potassium chloride buffer) and 4.5 (acetic acid/sodium acetate buffer); 15 min later the absorbance of each equilibrated solution was measured at the maximum wavelength of absorption and $700 \mathrm{~nm}$. The dilution factor (DF) was determined (final volume on the original sample volume). The difference in absorbance values at $\mathrm{pH} 1.0$ and 4.5 is directly proportional to the TMA concentration. The anthocyanin content was calculated as cyanidin-3-glycoside (MW = $449.2 \mathrm{~g} / \mathrm{mol}$ and $\xi=26,900 \mathrm{~L} / \mathrm{mol} . \mathrm{cm})$, and the results were expressed as $\mathrm{mg}$ of cy-3-glycoside $/ \mathrm{g}$ dry material. The absorbance of the diluted sample (A) and the TMA were calculated with Equations 2 and 3:

$$
A=\left(A_{M A X}-A_{700}\right)_{p H ~ 1,0}-\left(A_{M A X}-A_{700}\right)_{p H 4,5}
$$

(2)

$T M A(m g / L)=\left(A * M W^{*} \mathrm{DF}^{*} 1000\right) /(\xi * 1)$

(3)

\section{RESULTS AND DISCUSSION}

\subsection{Drying Kinetics}

Figure 1 shows the drying kinetics of jabuticaba peel at different temperatures $\left(50{ }^{\circ} \mathrm{C}, 60\right.$ ${ }^{\circ} \mathrm{C}$ and $70{ }^{\circ} \mathrm{C}$ ). Initially, the jabuticaba peel had a moisture content of 3.56 on a dry basis, and after drying the final moisture content was 0.21 on a dry basis. When analyzing Figure 1 , it is observed that the drying kinetics for the three studied temperatures presented two periods, a short period at a constant rate at the beginning of the process, followed by a predominant period of the decreasing rate. 


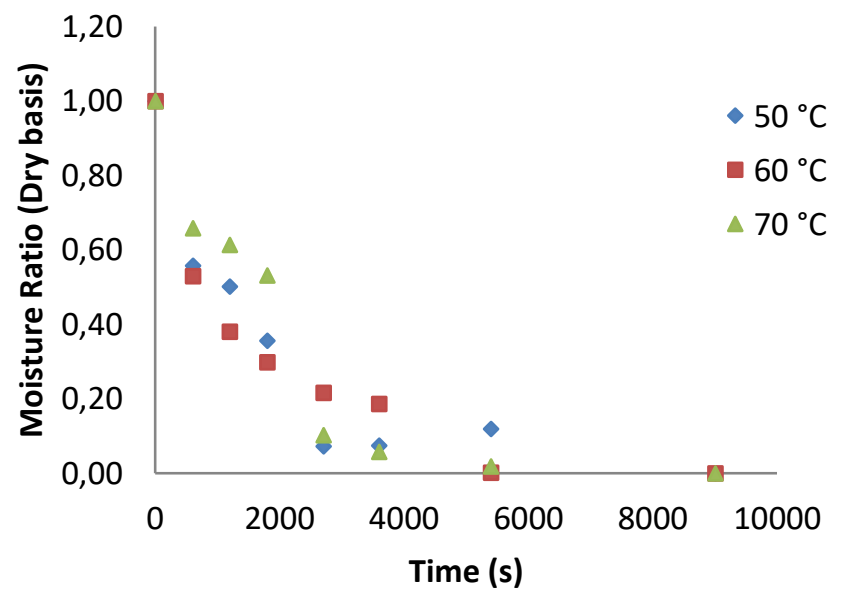

Figure 1: Drying kinetics of jabuticaba peel in spouted bed dryer at different temperatures.

At the beginning of the process, there was a rapid decrease of moisture due to a large amount of water present on the surface, and with that, it did not show a resistance of the internal material structure, being easily evaporated. From that moment, the internal resistances become prevailing, and consequently, the water replacement on the surface become difficult. This behavior is similar to the one reported by Mussi et al. (2015) [12] who studied the drying of jambolão residue in spout bed, and also the work of Oliveira et al. (2007) [13] with the drying of Carioca bean in spout bed dryer.

In order to describe mathematically the experimental data of the spouted bed drying, some empirical models were selected, and the found profiles for each model can be observed in Figures 2,3 and 4 for the temperatures of $50^{\circ} \mathrm{C}, 60^{\circ} \mathrm{C}$ and $70{ }^{\circ} \mathrm{C}$, respectively.

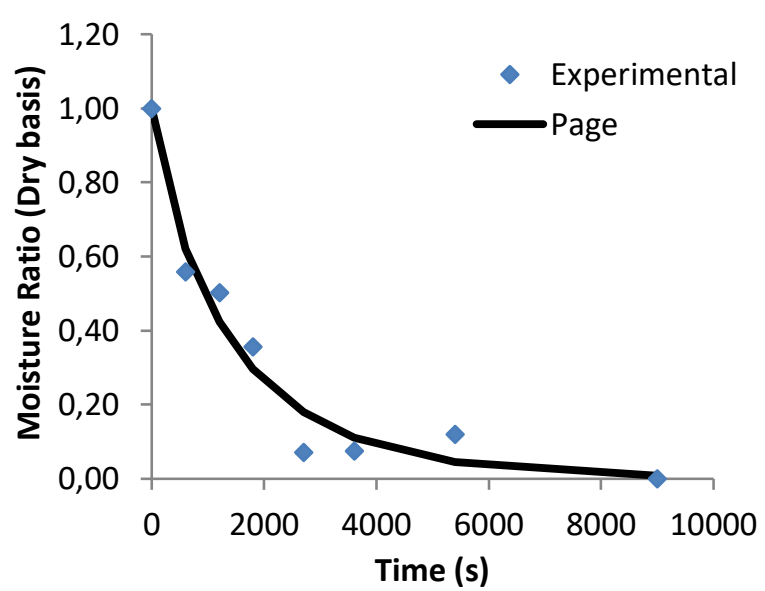

(a)

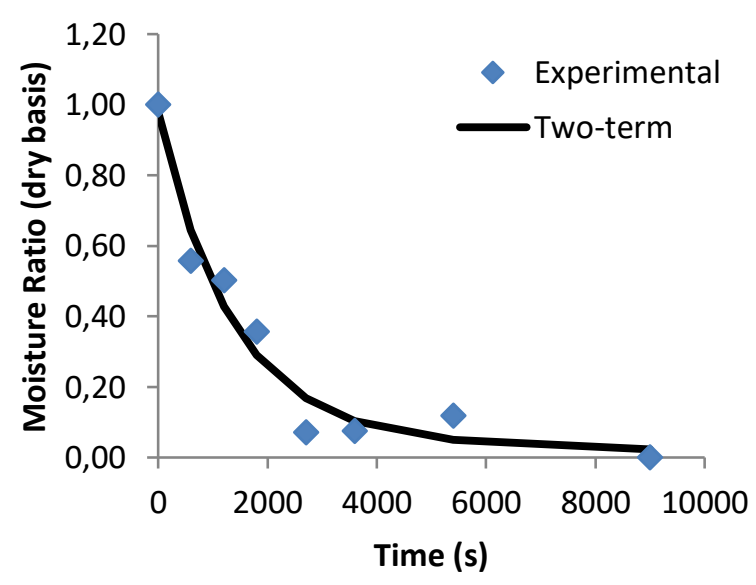

(b) 


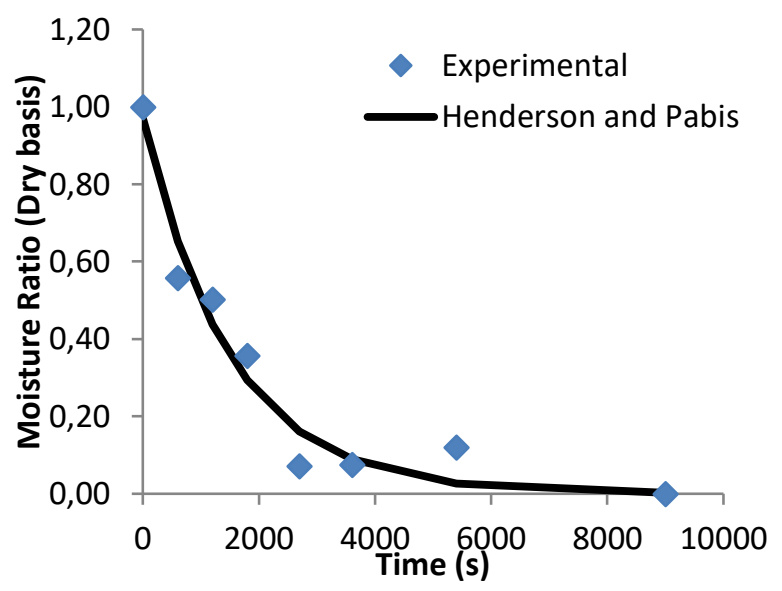

(c)

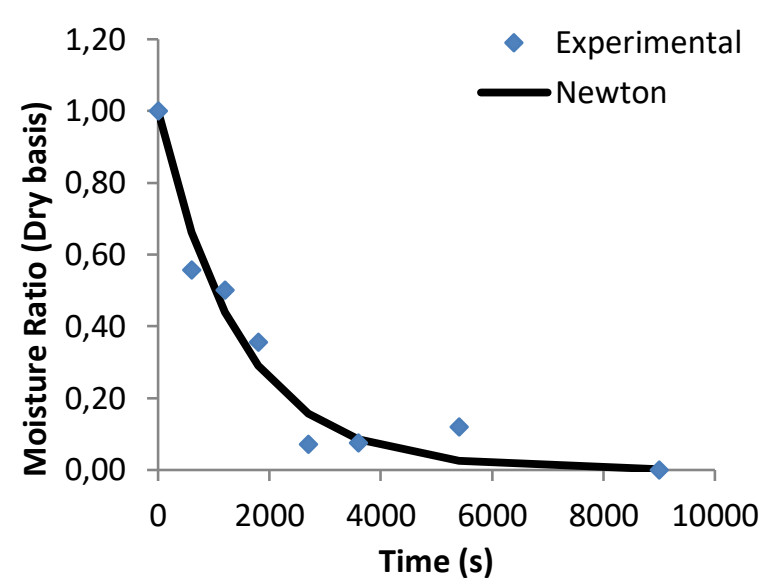

(d)

Figure 2: Graphical representation of the experimental and predicted data at $50^{\circ} \mathrm{C}$.

(a) Page Model; (b) Two-term Model; (c) Henderson and Pabis Model; (d) Newton Model.

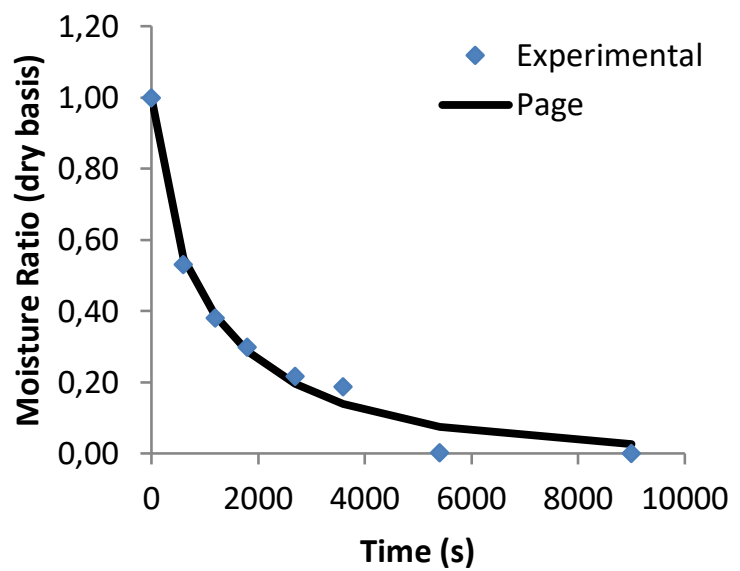

(a)

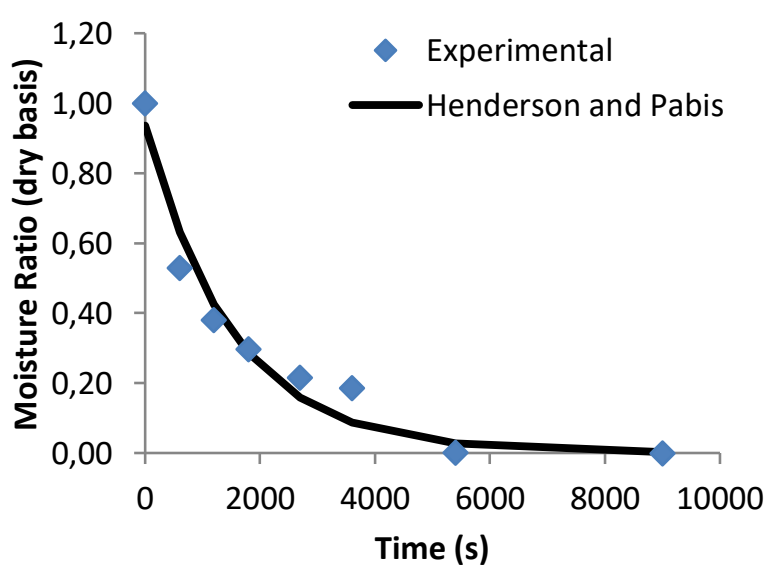

(c)

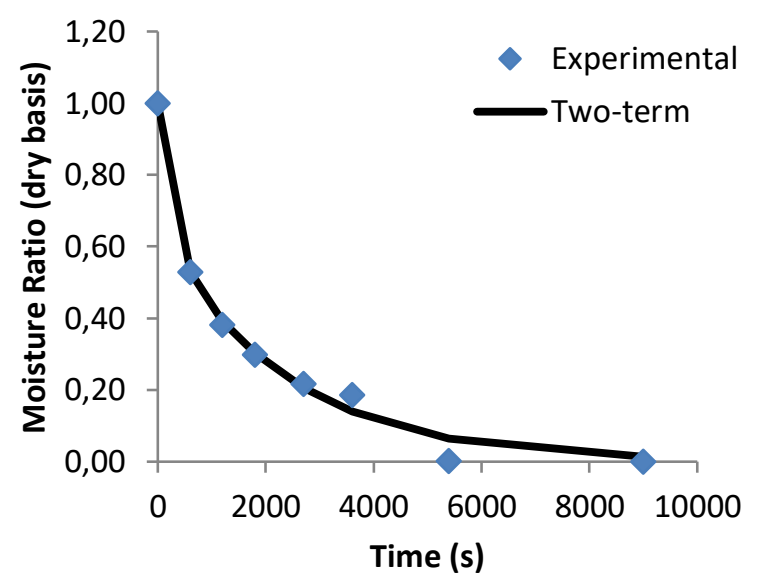

(b)

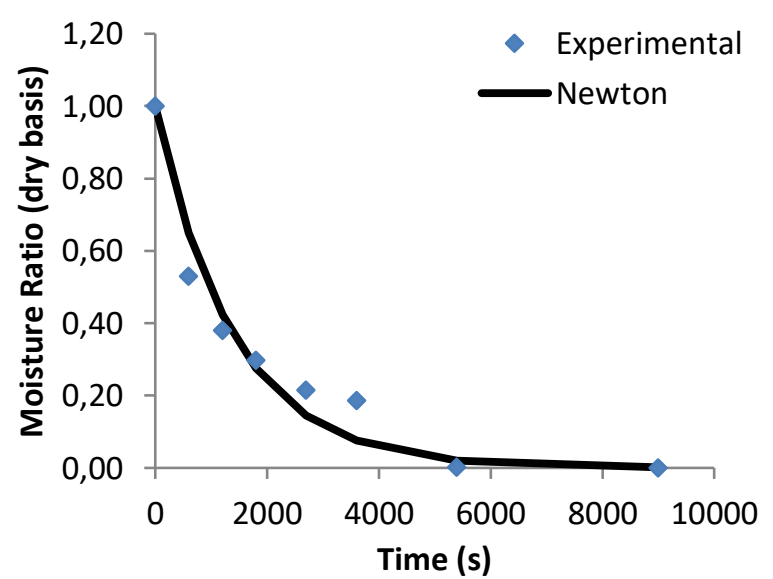

(d)

Figure 3: Graphical representation of the experimental and predicted data at $60^{\circ} \mathrm{C}$. (a) Page Model; (b) Two-term Model; (c) Henderson and Pabis Model; (d) Newton Model. 


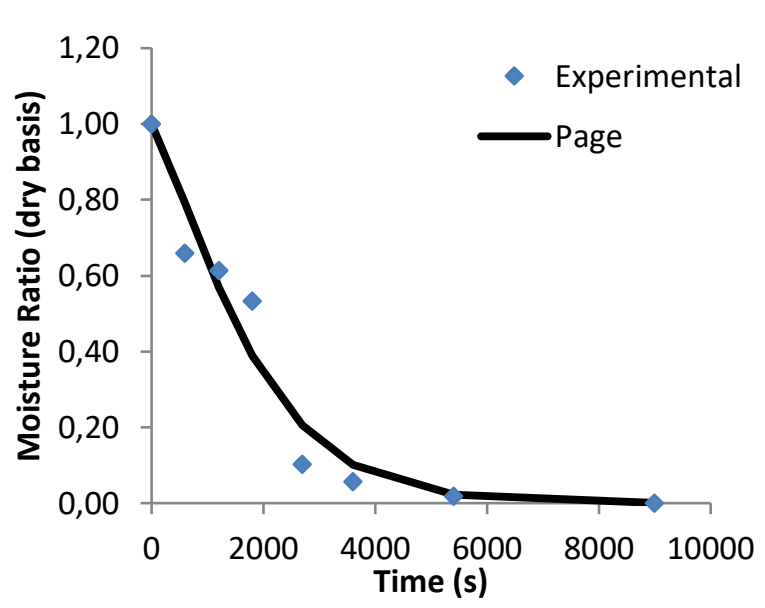

(a)

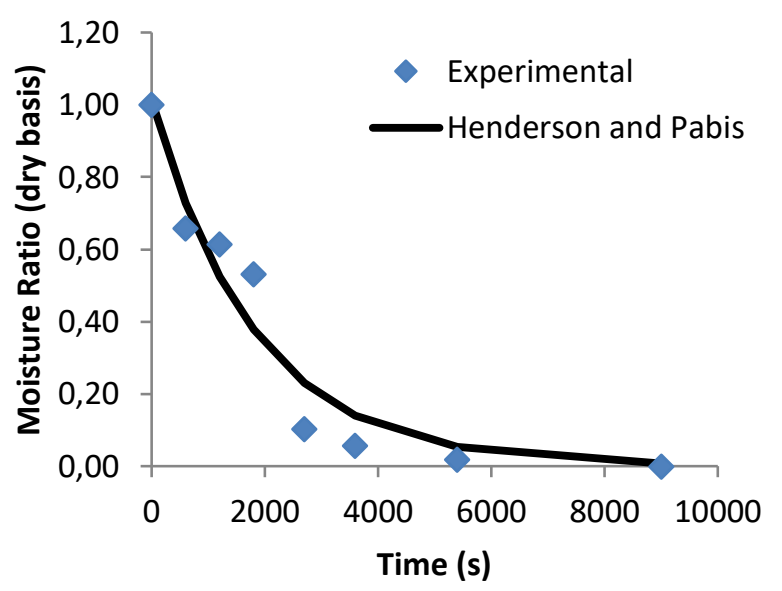

(c)

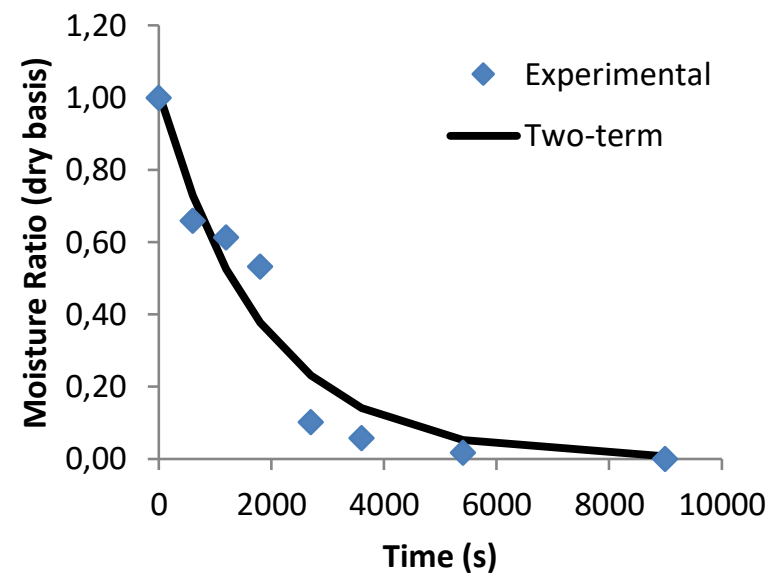

(b)

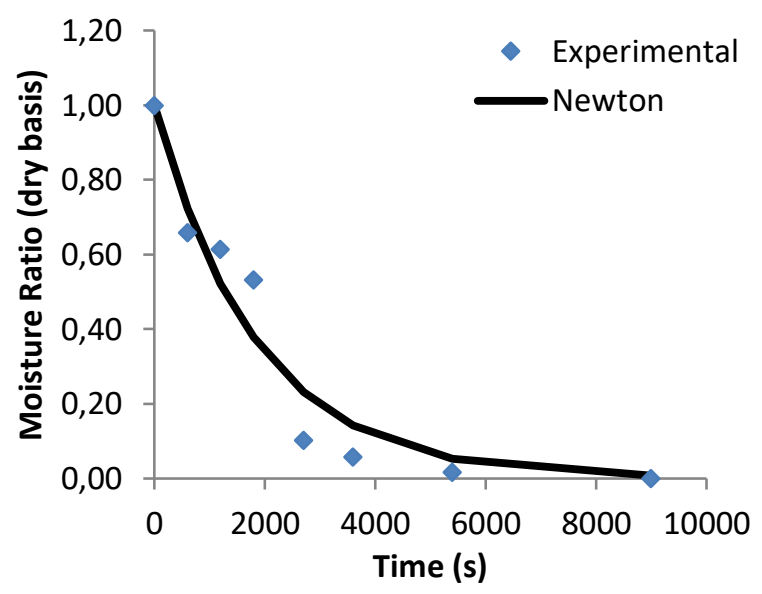

(d)

Figure 4: Graphical representation of the experimental and predicted data at $70^{\circ} \mathrm{C}$. (a) Page Model; (b) Two-term Model; (c) Henderson and Pabis Model; (d) Newton Model. 3.

The parameters determined by the models using nonlinear regression are found in Table

Table 3: Parameters determined by the models for the jabuticaba drying.

\begin{tabular}{|c|c|c|c|c|c|}
\hline \multirow[t]{2}{*}{ Mathematical Models } & & \multicolumn{4}{|c|}{ Parameters } \\
\hline & $\mathrm{T}\left({ }^{\circ} \mathrm{C}\right)$ & $\mathrm{k}$ & $\mathrm{n}$ & - & - \\
\hline \multirow{3}{*}{ Page } & 50 & $2.04 \times 10^{-3}$ & 0.853 & - & - \\
\hline & 60 & $8.47 \times 10^{-3}$ & 0.666 & - & - \\
\hline & 70 & $6.87 \times 10^{-5}$ & 1.271 & - & - \\
\hline \multirow{4}{*}{ Henderson and Pabis } & & $\mathrm{k}$ & $\mathrm{a}$ & - & - \\
\hline & 50 & $6.64 \times 10^{-4}$ & 0.971 & - & - \\
\hline & 60 & $6.60 \times 10^{-4}$ & 0.936 & - & - \\
\hline & 70 & $5.48 \times 10^{-4}$ & 1.012 & - & - \\
\hline \multirow{4}{*}{ Newton } & & $\mathrm{k}$ & - & - & - \\
\hline & 50 & $6.86 \times 10^{-4}$ & - & - & - \\
\hline & 60 & $7.17 \times 10^{-4}$ & - & - & - \\
\hline & 70 & $5.41 \times 10^{-4}$ & - & - & - \\
\hline \multirow{4}{*}{ Two-term } & & $\mathrm{a}$ & $\mathrm{b}$ & $\mathrm{K} 0$ & $\mathrm{~K} 1$ \\
\hline & 50 & 0.063 & 0.916 & $1.19 \times 10^{-4}$ & $7.49 \times 10^{-4}$ \\
\hline & 60 & 0.654 & 0.346 & $4.29 \times 10^{-4}$ & $4.53 \times 10^{-3}$ \\
\hline & 70 & 0.504 & 0.508 & $5.48 \times 10^{-4}$ & $5.48 \times 10^{-4}$ \\
\hline
\end{tabular}


Through the coefficient of determination of the predicted and experimental data it is possible to observe that all the models had good adjustments to the experimental data, but in order to identify which one was the best fit; performance indicators (Table 2) were used. In Table 4, the values of the performance indicators for each model can be observed in the three temperatures studied.

Table 4: Performance indicators outputs.

\begin{tabular}{|c|c|c|c|c|c|}
\hline \multirow{2}{*}{$\begin{array}{l}\text { Mathematical } \\
\text { Models }\end{array}$} & & \multicolumn{4}{|c|}{ Performance Indicators } \\
\hline & $\begin{array}{c}\mathrm{T} \\
\left({ }^{\circ} \mathrm{C}\right)\end{array}$ & RMSE & $A_{f}$ & $B_{f}$ & $\mathrm{R}^{2}$ \\
\hline \multirow{3}{*}{ Page } & 50 & 0.063 & 1.010 & 1.410 & 0.980 \\
\hline & 60 & 0.034 & 1.502 & 1.680 & 0.993 \\
\hline & 70 & 0.081 & 1.165 & 1.286 & 0.973 \\
\hline \multirow{4}{*}{ Henderson and Pabis } & & RMSE & $A_{f}$ & $B_{f}$ & \\
\hline & 50 & 0.066 & 0.914 & 1.452 & 0.979 \\
\hline & 60 & 0.061 & 1.238 & 1.668 & 0.979 \\
\hline & 70 & 0.087 & 1.344 & 1.524 & 0.969 \\
\hline \multirow{4}{*}{ Newton } & & RMSE & $A_{f}$ & $B_{f}$ & \\
\hline & 50 & 0.067 & 0.899 & 1.453 & 0.978 \\
\hline & 60 & 0.066 & 1.175 & 1.665 & 0.976 \\
\hline & 70 & 0.088 & 1.348 & 1.530 & 0.968 \\
\hline \multirow{4}{*}{ Two-term } & & RMSE & $A_{f}$ & $B_{f}$ & \\
\hline & 50 & 0.064 & 1.005 & 1.379 & 0.979 \\
\hline & 60 & 0.029 & 1.491 & 1.628 & 0.995 \\
\hline & 70 & 0.088 & 1.345 & 1.525 & 0.969 \\
\hline
\end{tabular}

According to Ross (1996) [14], the RMSE indicator compares the experimental and predicted values, and the model that best represents the experimental data should present a reduced value for this indicator. Thus, for drying at $50{ }^{\circ} \mathrm{C}$, the model with the lowest result is the Page model. However, the difference between the Page model and the others is minimal, and it probably does not have a difference between the models for this parameter.

The bias factor $\left(\mathrm{B}_{\mathrm{f}}\right)$ is the parameter that best evaluates the model performance since it relates to the agreement between the predicted and observed values being the better model performance when the $\mathrm{B}_{\mathrm{f}}$ is closest to 1 . For the temperature under discussion, this parameter was closer to 1 in the two-term model, indicating a better data agreement. The accuracy factor $\left(\mathrm{A}_{\mathrm{f}}\right)$ indicates the average difference between the predicted and observed data, and thus, the smaller the mean, the more appropriate is the model. Observing Table 4 it can be observed that the smallest value of $\mathrm{A}_{\mathrm{f}}$ indicator is Newton model. Therefore, for the drying at $50{ }^{\circ} \mathrm{C}$, it is not possible to conclude which model is best fit to the experimental data, since it does not show any agreement between the parameters for each model studied.

For the drying at $60{ }^{\circ} \mathrm{C}$, the model that best fit the experimental data was the Two-term model, where the RMSE indicator has the lowest value, as well as the $\mathrm{B}_{\mathrm{f}}$ indicator, is closer to 1 . On the other hand, for the drying at $70{ }^{\circ} \mathrm{C}$, the most suitable model for representing the experimental data is the Page model, which shows agreement with all studied indicators. As it can be seen in Table 4, the RMSE indicator has the smallest value for this model, and the $A_{f}$ and $\mathrm{B}_{\mathrm{f}}$ indicators are closer to 1 .

In comparison with other works for spouted bed dryer, Magalhães et al. (2008) [15], who evaluated the kinetics of cork stopper drying, found that the Two-term model better described its process, which is similar to the result of the drying at $60{ }^{\circ} \mathrm{C}$ in the present work. 


\subsection{Anthocyanin Content}

Table 5 shows the results of the anthocyanin analysis before and after each drying. According to the results, drying at $70{ }^{\circ} \mathrm{C}$ was the one that most degraded this compound, which was already expected because the anthocyanins are heat sensitive compounds. However, drying at $60{ }^{\circ} \mathrm{C}$ showed the lowest degradation, having a reduction of 5 times to the value found in the fresh peel. Similar behavior was observed in the paper of Alves (2011) [16] about drying jabuticaba peel in conventional dryer, in which a lower degradation of the anthocyanins was observed at the intermediate temperature studied $\left(45^{\circ} \mathrm{C}\right)$.

In the present work, this result may be related to the sampling factor. Due to the fact that the jabuticaba peel drying in spouted bed dryer is not very stable and occurs some agglomerations during the process, the sampling after drying at $60{ }^{\circ} \mathrm{C}$ may contain some peels that are still slightly wet and may not have had a strong drying effect. Consequently, the anthocyanins have not degraded as much as for dried samples, which contributed to the final content to a higher value.

Table 5: Anthocyanin content before and after drying in spouted bed dryer at different temperatures.

\begin{tabular}{lll}
\hline & $\begin{array}{l}\text { Anthocyanin Content (mg of cy-3-glycoside/g dry } \\
\text { material) }\end{array}$ \\
\cline { 2 - 3 } Drying Temperature $\left({ }^{\circ} \mathrm{C}\right)$ & Fresh & After drying \\
\hline 50 & & 4.50 \\
60 & 51.21 & 10.27 \\
70 & & 0.61 \\
\hline
\end{tabular}

The results presented in this work for the jabuticaba peel before drying is superior to that found by Santos et al. (2010) [17]. In his study, the extraction of antioxidant compounds from the jabuticaba peel was done with different methods, and it was obtained lower and similar values to $6 \mathrm{mg}$ of cy-3-glycoside / $\mathrm{g}$ dry matter.

\section{CONCLUSION}

It was observed that at $60{ }^{\circ} \mathrm{C}$ and $70{ }^{\circ} \mathrm{C}$, the Two-term and Page models, respectively, are adequate to describe the drying kinetic of the jabuticaba peel in spouted bed dryer in the studied conditions. At $50{ }^{\circ} \mathrm{C}$, it was not possible to indicate which model is the best fit.

For anthocyanins, it was possible to observe that there was a greater degradation at the highest studied temperature $\left(70{ }^{\circ} \mathrm{C}\right)$, as expected since anthocyanins are heat sensitive compounds.

The study of the drying process, the models the best represent this process to avoid future experiments, and knowing the temperature that causes less degradation, the anthocyanins from the jabuticaba peel can be studied in order to get benefit from its good characteristics to human health, and adding value to this fruit and avoiding the disposal of this residue.

\section{ACKNOWLEDGEMENTS}

The authors are thankful to the Federal University of Sergipe for the infrastructure and CNPq for the research support with scholarships.

\section{REFERENCES}

1. Brunini MA., Oliveira AL, Salandini CAR, Bazzo FR. Influência de embalagens e temperaturas no armazenamento de jabuticabas (Myrciaria jabuticaba (Vell) Berg.) cv. 'Sabará'. Ciênc Tecnol Aliment. 2004 Jul/Set;24(3):378-383, doi:10.1590/S0101-20612004000300013

2. Nunes JS, Castro DS, Moreira IS, Sousa FC, Silva WP. Descrição cinética de secagem da polpa de jabuticaba usando modelos empíricos. Revista Verde de Agroecologia e Desenvolvimento Sustentável. 2014;9(1):20-26.

3. Turker N, Erdogdu F. Effects of $\mathrm{pH}$ and temperature of extraction medium on effective diffusion coefficient of anthocynanin pigments of black carrot (Daucus carota var. L.). Journal of Food Engineering. 2006;76:579-583, doi:10.1016/j.jfoodeng.2005.06.005 
4. Abreu H, Ferreira SMR. Extração e encapsulação de antocianinas de Jabuticaba (Myrciaria cauliflora), Açaí (Euterpe oleracea) e Uva Isabel (Vitis labrusca). In: $8^{\circ}$ Encontro de Engenharia e Tecnologia dos Campos Gerais; $2013 \quad 27-30 \quad$ agosto; Disponível em < http://www.aeapg.org.br/8eetcg/anais/60176_vf1.pdf>

5. Veggi PC, Santos DTM, Meireles AA. Anthocyanin extraction from Jabuticaba (Myrciaria cauliflora) skins by different techniques: economic evaluation. Procedia Food Science. 2011;1:1725-1731, doi:10.1016/j.profoo.2011.09.254

6. Citadin I, Danner MA, Sasso SAZ. Jabuticabeiras. Revista Brasileira de Fruticultura. 2010;32(2):343656.

7. Celestino SMC. Princípios de Secagem de Alimentos. Planaltina, DF: Embrapa Cerrados; 2010. p. 1718.

8. Park KJ, Yado MKM, Brod FPR. Estudo de secagem de pêra bartlett (Pyrus sp.) em fatias. Ciênc Tecnol Aliment. 2001;21(3):288-292, doi:10.1590/S0101-20612001000300007

9. Pontes Júnior SM, Dantas SCM, Delmiro TM, Medeiros MFD. Secagem de polpas de frutas em leito de jorro. Efeitos da adição de leites vegetal e animal e da proteína isolada de leite no desempenho do processo e qualidade do produto em pó produzido. In: XI congresso Brasileiro de Engenharia Química em Iniciação Científica. Unicamp-SP. São Paulo: Blucher; 2015, p. 2069-2074, doi:10.5151/chemengcobeqic2015-070-32095-243676

10. Dung NV, Fowler RT, Bowrey RG. Variables affecting the drying rate of paddy rice. Food Technology. 1980;32(12):604-606.

11. Wrolstad RE, Giusti MM. Characterization and measurement of Anthocyanins by UV-visible spectroscopy. Current Protocols in Food Analytical Chemistry. John Wiley \& Sons, New York; 2001, doi:10.1002/0471142913.faf0102s00

12. Mussi LP, Guimarães AO, Ferreira KS, Pereira NR. Spouted bed drying of jambolão (Syzygium cumini) residue: Drying kinetics and effect on the antioxidant activity, anthocyanins and nutrients contents. Food Science and Technology. 2015;61:80-88, doi:10.1016/j.1wt.2014.11.040

13. Oliveira CA, Rocha SCS. Intermittent drying of beans in a spouted bed. Brazilian Journal of Chemical Engineering. 2007;24(4):571-585, doi:10.1590/S0104-66322007000400010

14. Ross T. Indices for performance evaluation of predictive models in food microbiology. J Appl Bacteriol. 1996;81:501-508, doi:10.1111/j.1365-2672.1996.tb03539.x

15. Magalhães A, Pinto C. Spouted bed drying of cork stoppers. Chemical Engineering and Processing. 2008;47:2395-2401, doi:10.1016/j.cep.2007.11.009

16. Alves APC. Casca de jabuticaba (Plinia jabuticaba (vell.) berg): Processo de secagem e uso como aditivo em iogurte [Dissertação]. Programa de Pós graduação em Agroquímica; 2011. 91 p.

17. Santos DT, Veggi PC, Meireles MAA. Extraction of antioxidant compounds from Jabuticaba (Myrciaria Cauliflora) skins: Yield, composition and economical evaluation. Journal of Food Engineering. 2010;101: 23-31, doi:10.1016/j.jfoodeng.2010.06.005 